\title{
Enantioselective Vicinal Diacetoxylation of Alkenes under Chiral lodine(III) Catalysis
}

\author{
Thorsten H. Wöste ${ }^{a, 1}$ \\ Kilian Muñiz*a,b \\ a Institute of Chemical Research of Catalonia (ICIO), \\ The Barcelona Institute of Science and Technology, \\ Av. Països Catalans 16, 43007 Tarragona, Spain \\ b Catalan Institution for Research and Advanced \\ Studies (ICREA), Pg. Lluís Companys 23, 08010 \\ Barcelona, Spain \\ kmuniz@iciq.es
}
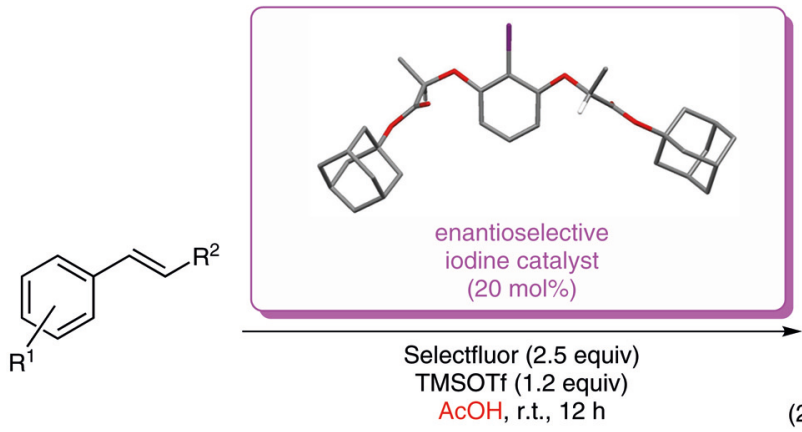

Received: 17.11.2015

Accepted after revision: 14.12.2015

Published online: 13.01 .2016

DOI: 10.1055/s-0035-1561313; Art ID: ss-2015-t0664-fa

Abstract A procedure for the intermolecular enantioselective dioxygenation of alkenes under iodine(III) catalysis has been developed. This protocol employs Selectfluor as the terminal oxidant together with a defined $C_{2}$-symmetric aryl iodide as the organocatalyst. This enantioselective reaction proceeds under mild conditions and converts a series of terminal and internal styrenes into the corresponding vicinal diacetoxylation products with up to $96 \%$ ee.

Key words alkenes, chirality, diacetoxylation, hypervalent iodine, oxidation, Selectfluor

As a synthetic concept, the vicinal difunctionalization of alkenes allows for a rapid structural and functional diversification of simple alkene moieties within a single operation. ${ }^{2}$ Among the many examples of this type of reactions, the development of processes that proceed entirely under intermolecular reaction control is of particular challenge. While this field has been largely dominated by enantioselective transition metal catalysis such as the seminal osmium-based dihydroxylation and aminohydroxylation processes developed by Sharpless, ${ }^{3}$ chiral nonracemic iodine(III) reagents ${ }^{4}$ have recently emerged as potentially versatile alternatives. ${ }^{5}$ Based on earlier work on defined iodine(III) reagents for selective dioxygenation of alkenes, ${ }^{5 c, 6}$ the development of the corresponding enantioselective dioxygenation reactions was pioneered and extensively investigated by Wirth. ${ }^{7}$ These reactions made use of defined chiral iodine(III) reagents such as $\mathbf{1}$, and the oxidation of styrene $\mathbf{2 a}$ led to the formation of the corresponding ditosylation product 3a' with up to $65 \%$ ee (Scheme 1). The appearance of the chiral bislactate derived iodine(III) oxidant 4a has greatly advanced the inherent synthetic possibilities, ${ }^{5,8}$ and, based on this reagent, an enantioselective diace-

toxylation of $\mathbf{2 a}$ subsequently led to the formation of the corresponding diacetoxylated product $\mathbf{3 a}$ in up to $89 \%$ ee (Scheme 1). ${ }^{9}$ A related diamination ${ }^{10}$ was also developed using stoichiometric amounts of 4a. Moreover, an amide derivative of $\mathbf{4 a}$ promoted an oxygenative rearrangement reaction, ${ }^{11 a}$ an Umpolung functionalization of silylated enol ethers, ${ }^{11 b}$ and asymmetric Kita-spirolactonization reac-

Wirth (1998):
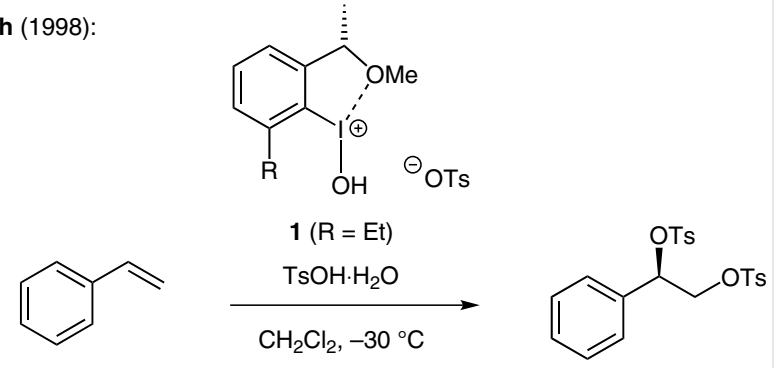

$2 a$

$3 a^{\prime}(65 \%$ ee)

Fujita (2011):

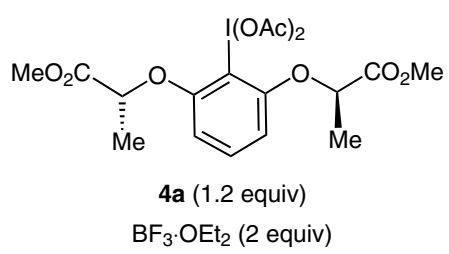

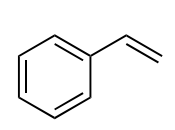

2a
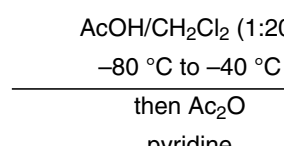

pyridine

$68 \%$<smiles>CC(=O)OC[C@H](OC(C)=O)c1ccccc1</smiles>

3a $(89 \%$ ee $)$
Scheme 1 Intermolecular vicinal dioxygenation reactions of styrene with stoichiometric amounts of hypervalent iodine(III) promoters 


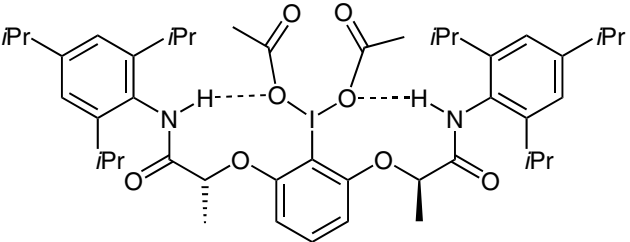

$4 \mathrm{~b}$

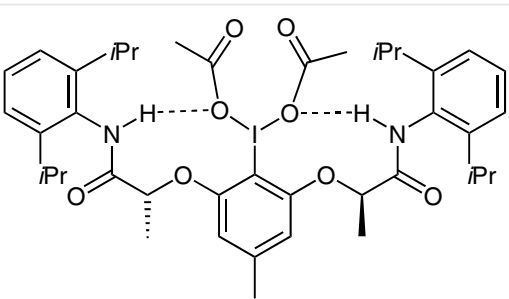

$4 c$
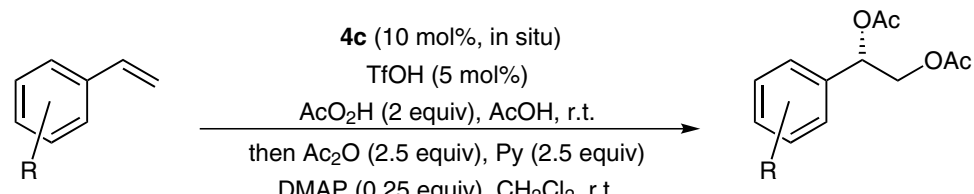

Figure 1 Intramolecular hydrogen bonding properties of chiral hypervalent iodine compounds $\mathbf{4 b}, \mathbf{c}$ and catalytic enantioselective diacetoxylation of styrenes

tions. ${ }^{11 c-e}$ In addition, important contributions were also achieved in the field of related intramolecular enantioselective reactions of alkene oxidation. ${ }^{5,12,13}$ In the case of the latter, Fujita recently reported that such oxidations could also be conducted with catalytic amounts of $\mathbf{4 a}$ in the presence of $m$-CPBA as terminal oxidant. ${ }^{5,14,15}$
However, despite the fact that dioxygenation belongs to the most extensively investigated reactions in iodine(III)mediated oxidation of alkenes, ${ }^{16}$ the development of corresponding reaction conditions for strictly intermolecular difunctionalization under iodine(III) catalysis represents an ongoing challenge. ${ }^{17}$

\section{Biographical Sketches}
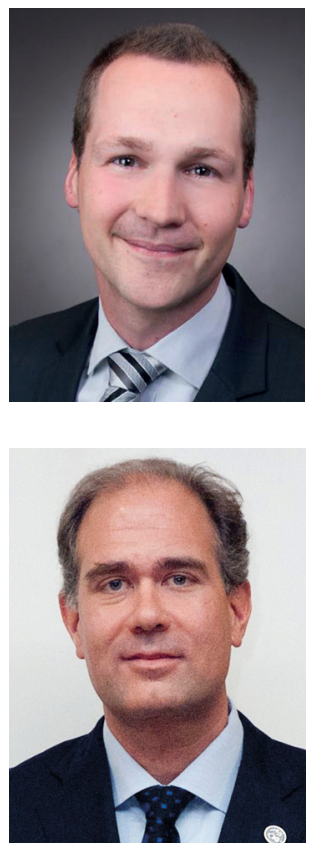

Thorsten H. Wöste was born in 1983 in Sögel, Germany. He received his Diploma degree under the supervision of Prof. Dr. Martin Oestreich at the Westfälische Wilhelms-Universität Münster, Germany in 2009 and his Ph.D. in 2012. He was

Kilian Muñiz was born in 1970 in Hildesheim, Germany. He studied Chemistry at the Universities of Hannover (Germany) and Oviedo (Spain), and at the Imperial College London (UK). He received a Doctorate in Chemistry from the RWTH Aachen in 1998 for work with Professor Carsten Bolm and was an Alexander von Humboldt/ JSPS-postdoctoral associate involved in catalytic asymmetric (Mizoroki-)Heck reactions in Münster as well as at the Technische Universität Berlin. In December 2012, Thorsten joined the group of Prof. Dr. Kilian Muñiz as a postdoctoral fellow, funded by the Deutsche For- schungsgemeinschaft (DFG). His research was focused on metal-free, hypervalent iodine catalyzed difunctionalization of alkenes. Currently, Thorsten is working as $\mathrm{R} \& \mathrm{D}$ Manager at Convertec $\mathrm{GmbH}$, Germany.

with Professor Ryoji Noyori at Nagoya University (Japan). From 2001-2005 he was a Liebig fellow at Bonn University associated with Professor Karl Heinz Dötz, before accepting a full professorship at Strasbourg University (France). He was elected as a junior member of the Institute Universitaire de France in 2008. He moved to his present position at ICIQ in Tarragona
(Spain) in 2009. Since 2010 he has also been an ICREA research Award for Excellence in Research from the Royal Spanish Chemical Society (RSEQ). His research throughout the past decade has dealt with the development of new processes in the area of vicinal difunctionalization, in particular with the oxidative diamination of alkenes. professor. He received a 2015 
This is a noteworthy observation, in particular when taking into account the potential that a metal-free process would have for applications in fields such as biological and medicinal synthesis, where the avoidance of metal contamination is of major importance. We have recently introduced new derivatives of chiral hypervalent iodine reagents of the Ishihara motif, which led to catalyst structures based on effective hydrogen bonding (Figure 1). ${ }^{18}$

These compounds indeed enabled the catalytic enantioselective diacetoxylation of styrenes under intermolecular reaction control with up to $94 \%$ ee. Despite the success of these new catalysts, we remained curious to explore whether the parent diesters such as $\mathbf{4 a}$ could be employed as catalysts as well. We report here the development of suitable conditions for such an enantioselective diacetoxylation of alkenes using catalytic amounts of an iodine(I/III) catalysis with $\mathbf{4 a}$ and related derivatives.
Although different oxygen sources such as perchlorate, trifluoroacetate, and tosylate have become available, ${ }^{16}$ we were particularly drawn to the development of a dioxygenation reaction using the more common acetate as nucleophile. Such a process would be based on chiral derivatives of the fundamental $\mathrm{PhI}(\mathrm{OAc})_{2}$ reagent. Its notoriously low reactivity towards alkenes is usually attributed to the diminished electrophilicity of the central iodine(III) atom. In an elegant study, Gade and Kang demonstrated that Brønsted activation of $\mathrm{PhI}(\mathrm{OAc})_{2}$ with triflic acid represents a powerful tool to accelerate the overall diacetoxylation process. ${ }^{19,20}$ Attempts to devise conditions for diacetoxylation reactions that are catalytic in iodine reagent have met with certain success, ${ }^{21}$ however, the potential contribution of background reactivity to the overall product formation ${ }^{22}$ remains an issue. Obviously, the use of a chiral iodine reagent would provide the possibility to employ enantioselectivity

Table 1 Optimization of the Catalytic Enantioselective Diacetoxylation

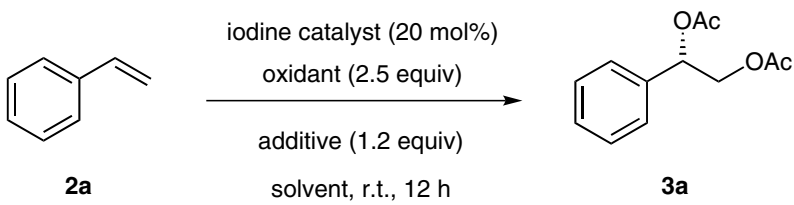

\begin{tabular}{|c|c|c|c|c|c|c|}
\hline Entry & $\mathrm{I}_{2}$ cat. & Oxidant & Additive & Solvent & Yield (\%) & ee $(\%)^{b}$ \\
\hline 1 & $4 a$ & $m$-СРВА & - & $\mathrm{AcOH} / \mathrm{CH}_{2} \mathrm{Cl}_{2}$ & n.c. ${ }^{c}$ & - \\
\hline 2 & $4 a$ & $m-С Р B A$ & TFA & $\mathrm{CH}_{2} \mathrm{Cl}_{2}$ & n.c. & - \\
\hline 3 & $4 a$ & $\mathrm{AcO}_{2} \mathrm{H}$ & - & $\mathrm{AcOH}$ & n.c. & - \\
\hline 4 & $4 a$ & $\mathrm{AcO}_{2} \mathrm{H}$ & TMSOTf & $\mathrm{AcOH}$ & n.c. & - \\
\hline 5 & $4 a$ & $\mathrm{NaOCl}$ & TMSOTf & $\mathrm{AcOH}$ & n.c. & - \\
\hline 6 & $4 a$ & Selectfluor & - & $\mathrm{AcOH}$ & n.c. & - \\
\hline 7 & $4 a$ & Selectfluor & $\mathrm{TfOH}$ & $\mathrm{AcOH}$ & 63 & 0 \\
\hline 8 & $4 a$ & Selectfluor & $\mathrm{MsOH}$ & $\mathrm{AcOH}$ & 38 & 0 \\
\hline 9 & $4 a$ & Selectfluor & TMSOTf & $\mathrm{AcOH}$ & 67 & 68 \\
\hline 10 & $4 a$ & Selectfluor & TMSOAC & $\mathrm{AcOH}$ & n.c. & - \\
\hline 11 & $4 a$ & Selectfluor & TMSOAc, TfOH & $\mathrm{AcOH}$ & 69 & 72 \\
\hline 12 & $4 a$ & Selectfluor & TMSOTf & $\mathrm{AcOH} / \mathrm{CH}_{2} \mathrm{Cl}_{2}$ & n.c. & - \\
\hline 13 & $4 a$ & Selectfluor & TMSOTf & $\mathrm{AcOH} / \mathrm{CHCl}_{3}$ & n.c. & - \\
\hline 14 & $4 a$ & Selectfluor & TMSOTf & $\mathrm{AcOH} /\left(\mathrm{CH}_{2} \mathrm{Cl}\right)_{2}$ & n.c. & - \\
\hline 15 & $4 a$ & Selectfluor & TMSOTf & $\mathrm{AcOH} / \mathrm{CCl}_{4}$ & n.c. & - \\
\hline 16 & $5 a$ & Selectfluor & TMSOTf & $\mathrm{AcOH}$ & 64 & 74 \\
\hline 17 & $5 e$ & Selectfluor & TMSOTf & $\mathrm{AcOH}$ & 67 & 52 \\
\hline 18 & $5 b$ & Selectfluor & TMSOTf & $\mathrm{AcOH}$ & 47 & 78 \\
\hline 19 & $5 c$ & Selectfluor & TMSOTf & $\mathrm{AcOH}$ & 63 & 78 \\
\hline 20 & $5 d$ & Selectfluor & TMSOTf & $\mathrm{AcOH}$ & 66 & 80 \\
\hline
\end{tabular}

a Isolated yield after treatment with $\mathrm{Ac}_{2} \mathrm{O}$.

b Determined by chiral HPLC analysis (OD-H column).

c n.c.: No conversion to 3 a was observed. 
as a tool to unambiguously prove the catalytic performance of the aryl iodine. Our approach to develop an enantioselective diacetoxylation of alkenes was started from $\mathbf{4 a}$ as the catalyst source and with styrene as the standard alkene (Table 1). Our initial attempts on the use of peracids as terminal oxidants ${ }^{15}$ for the present case of an intermolecular dioxygenation were quickly abandoned. In agreement with the earlier conclusion from Gade and Kang on achiral iodines, ${ }^{22}$ that due to similar kinetics, iodine(III) catalysis and stoichiometric oxidation by the stoichiometric oxidant itself compete for the alkene oxidation, aldehyde formation and other degradation products were observed. For the chiral reagent $\mathbf{4 a}$, reactions in the presence of $m$-CPBA, peracetic acid, or sodium hypochlorite lead to no diacetoxylation of styrene (2a) to the expected product 3a, regardless whether potential activating additives were added (Table 1 , entries 1-5).

We thus changed our approach and employed Selectfluor, which is known for its ability to promote stoichiometric iodine(III) formation from the corresponding aryl iodides. ${ }^{8 c, 23}$ While reagent $4 \mathbf{a}$ itself cannot promote a catalytic diacetoxylation of styrene in the sole presence of Selectfluor (Table 1, entry 6), addition of triflic acid demonstrated that turnover can be achieved, although the desired product 3a was formed as a racemate (entry 7). Less acid strength as with methylsulfonic acid results in a decrease in yield (entry 8). Finally, addition of TMS triflate gave a catalytic reaction that formed a product with $68 \%$ ee (entry 9 ). Changing the additive to TMS acetate shut down the reaction (entry 10 ), while the additional presence of triflic acid reactivated the enantioselective catalysis (entry 11). Attempts to carry out the reaction in solvent mixtures were not successful (entries 12-15). The reaction was then further developed exploring the potential of different in situ generated hypervalent iodine compounds. When starting the reaction from the corresponding iodine(I) compound 5a (Figure 2), an efficient catalysis was observed (entry 16). A related catalyst 5e with a single lactate side chain gave similar yield, but decreased ee (entry 17). A useful increase in enantioselectivity to $78 \%$ ee was observed for the tert-butyl ester $\mathbf{5 b}$, although the chemical yield decreased. The latter was attributed to a potential incompatibility of the tert-butyl ester with the TMS additive. Consequently, the new adamantyl derivatives $\mathbf{5 c}$ and $\mathbf{5 d}$ were synthesized and structurally characterized (Figure 3). ${ }^{24}$

The adamantyl-substituted catalysts were demonstrated to be efficient, giving the diacetoxylation product in up to $80 \%$ ee (entries 19,20 ). In particular, compound $\mathbf{5 d}$ displayed significantly higher stability than the tert-butyl ester $\mathbf{5 b}$, and could be recovered in over $95 \%$ isolated yield after the oxidation catalysis. In all these cases, in order to account for a uniform product, the crude reaction mixtures were treated with acetic anhydride prior to analysis of product 3a (cf. footnote a, Table 1).<smiles>CC(Oc1cccc(OC(C)C(=O)O)c1I)C(=O)O</smiles>

5a: $\mathrm{R}=\mathrm{Me}$

5c: $R=2$-adamantyl

5d: $R=1$-adamantyl 5b: $R=t B u$

Figure 2 Chiral iodine(I) catalysts: structures

The reaction is general for a range of styrenes. Scheme 2 displays 17 examples of different styrenes $\mathbf{2 a}-\mathbf{q}$ that could be converted into the corresponding diacetoxylation products 3a-q in an enantioselective manner. These examples demonstrate a higher substrate scope than reported for the stoichiometric reaction. ${ }^{9}$ The high robustness of the reaction conditions was further demonstrated for a $24 \mathrm{mmol}$ scale diacetoxylation of $\mathbf{2 a}$, which provided $2.99 \mathrm{~g}$ of the corresponding product $\mathbf{3 a}$.

Apart from styrene itself, several para-substituted arenes $\mathbf{2} \mathbf{b}-\mathbf{g}$ underwent diacetoxylation in good yields and with $64-86 \%$ ee. An exception was encountered in the case of 4-methoxystyrene, which suffered from degradation under the present conditions. Other successful examples in-

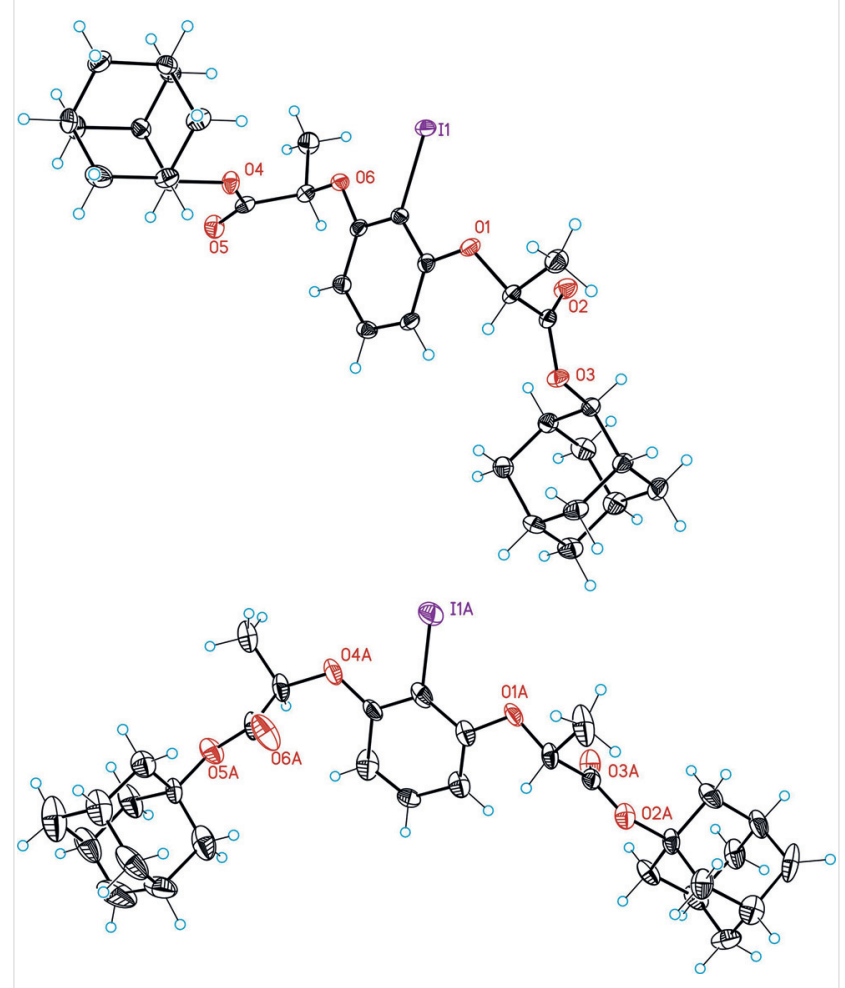

Figure 3 Solid state structures of compounds $\mathbf{5 c}$ (top) and $\mathbf{5 d}$ (bottom) 
clude the meta- and ortho-substituted products $\mathbf{3 h}-\mathbf{m}$, which formed with up to $88 \%$ ee. Higher-substituted styrenes $\mathbf{2 n - q}$ led to the formation of the corresponding diacetoxylation products $\mathbf{3 n - q}$ with good enantioselectivities of $62-64 \%$ ee. The enantioselectivity values obtained from such room temperature catalyses are noteworthy when compared to the outcome of the parent stoichiometric reaction, which was conducted at a temperature range between -80 and $-40{ }^{\circ} \mathrm{C} .{ }^{9}$ They are only slightly lower than the ones for the presently best enantioselective catalysis based on compounds $\mathbf{4 b}, \mathbf{c}{ }^{18}$

A mechanistic context for this intermolecular enantioselective iodine(III)-catalyzed dioxygenation reaction is discussed in Figure 4. The reaction starts with the Selectfluormediated oxidation of the iodine(I) species $\mathrm{Ar}^{*} \mathrm{I}$ to the cor- responding cationic iodine(III) catalyst state $\mathbf{A}$, which in the presence of trimethylsilyl acetate and triflic acid generates the catalyst state $\mathbf{B}$. Since the reaction proceeds in acetic acid as solvent, this pathway could initially proceed through the formation of the corresponding diacetoxyiodine(III) species, which upon protonolysis by triflic acid will ultimately generate $\mathbf{B}$. In any case, the presence of both the TMS group for removal of the fluoride and HOTf for the formation of a cationic catalyst state are required. In agreement with the data from Gade on the achiral reaction, ${ }^{19} \mathbf{B}$ should represent the active catalyst involved in the alkene oxidation. This was corroborated by a stoichiometric control experiment on diacetoxylation of styrene (2a) with $\mathbf{4 a}$ together with 1.2 equivalents of TMS triflate in acetic acid at room temperature (Scheme 3), which gave 3a (56\% yield,<smiles>[R]c1ccc(C=C)cc1</smiles> 
$73 \%$ ee) in a comparable outcome to the results from catalysis (Table 1, entry 11: 69\% yield, $72 \%$ ee). Upon oxidation of the styrene, the iodo-oxygenated intermediate $\mathbf{C}$ is formed, from which the iodine(I) catalyst is regenerated upon an intramolecular reductive displacement by the acetyl group forming the resulting dioxolonium derivative $\mathbf{D}$. It had previously been discussed ${ }^{16}$ that such an intermediate $\mathbf{D}$ can undergo ring opening by acetate through a Prévost mechanism ${ }^{25}$ or through water addition to form a hydroxyacetate 6 within a Woodward pathway. ${ }^{26}$ It should also be noted that both pathways from $\mathbf{D}$ release one equivalent of HOTf. However, the reaction does not proceed with catalytic amounts of HOTf, which should be the result of neutralization through the tertiary quinuclidinium amine that is generated from Selectfluor within the oxidation step.

To gain further insight on the involved intermediates in the dioxygenation, we isolated the direct reaction products
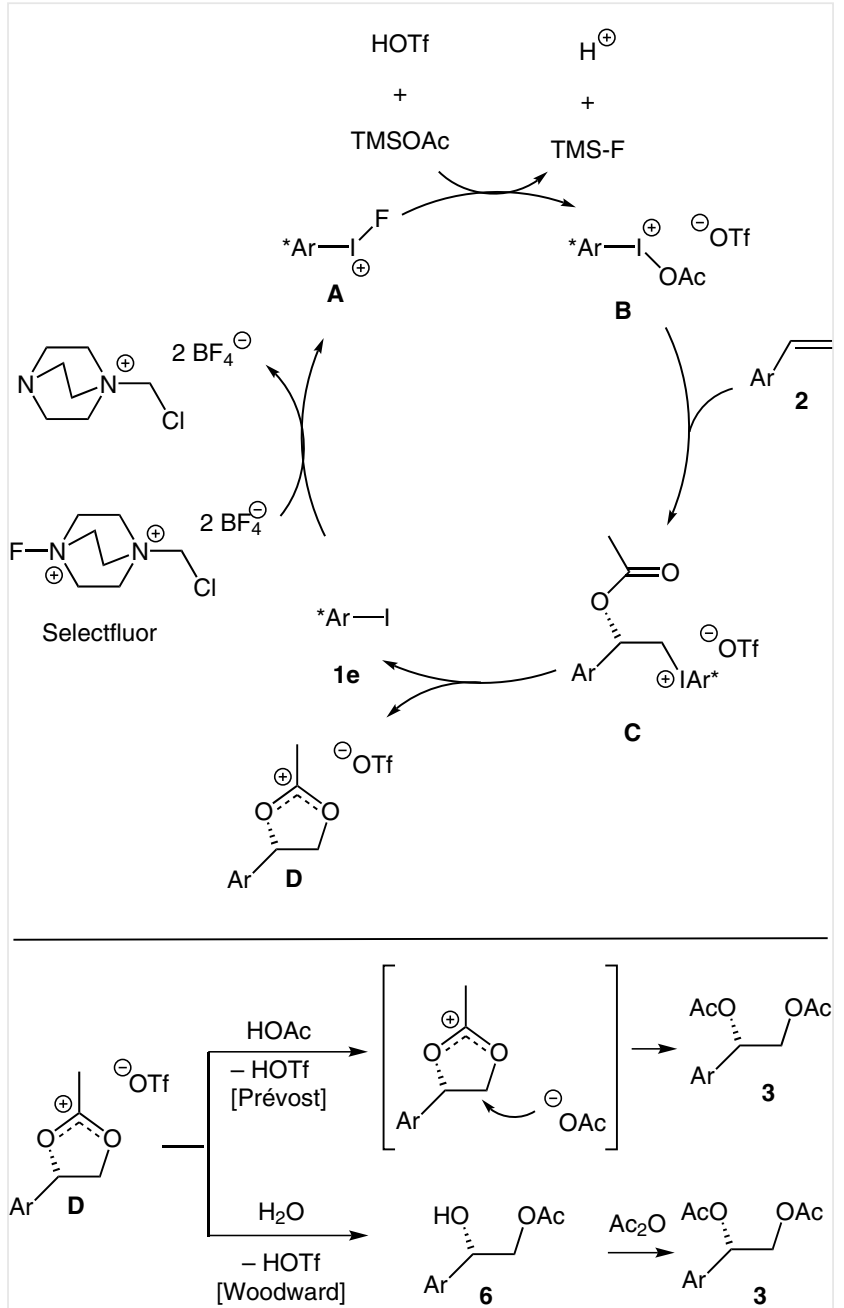

Figure 4 Catalytic cycle for the enantioselective diacetoxylation of styrenes

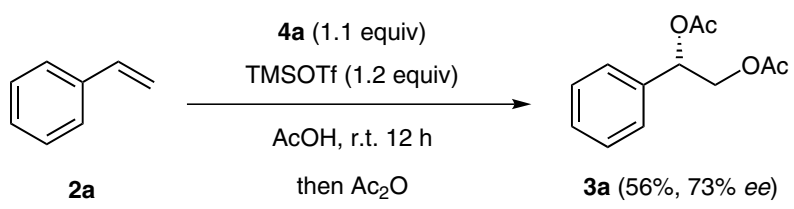

Scheme 3 Stoichiometric control experiment

from catalytic dioxygenation of styrene (2a) (Scheme 4). In this case, the crude reaction mixture contained both the diacetoxylation product $\mathbf{3} \mathbf{a}$ as well as the regioselectively formed 1-hydroxy-2-acetoxy product $\mathbf{6 a}$, indicating that two different pathways are competent under the reaction conditions. The diacetate 3a was isolated as the $S$-enantiomer in $42 \%$ yield with $80 \%$ ee, while the equally $S$-configured hydroxyacetate $\mathbf{6 a}$ was formed in $40 \%$ yield and with $80 \%$ ee as determined after conversion to the diacetate $\mathbf{3 a}$.

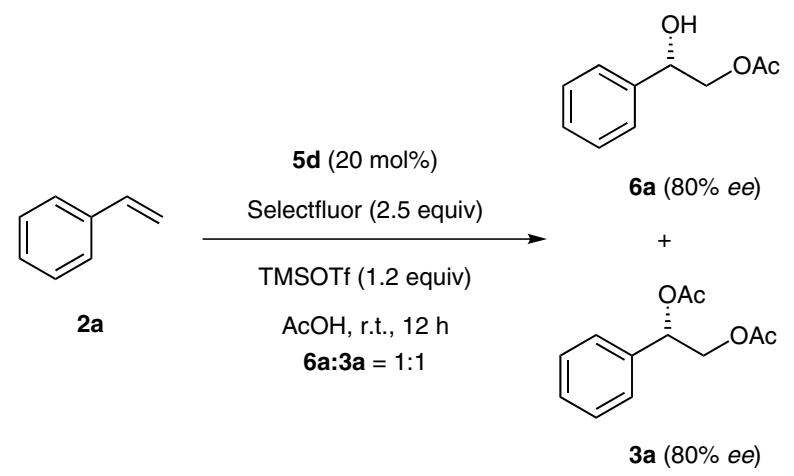

Scheme 4 Control experiment on the initial product distribution for terminal alkene oxidation

The fact that the two compounds $\mathbf{3 a}$ and $\mathbf{6 a}$ form with identical absolute configuration and identical enantiomeric excess is important. To account for the observed $S$-configuration of the diacetoxylation product through a Prévost pathway, an opening of intermediate $\mathbf{D}$ at the homobenzylic position is required. While this is not entirely impossible, it appears highly improbable. In fact, a Prévost mechanism was suggested to be involved in the stoichiometric dioxygenation, which provided the expected $R$-stereochemistry. ${ }^{9}$ The present observation on the stereochemical outcome suggests that a Prévost mechanism is not involved in this transformation and product $\mathbf{3 a}$ should form through a different pathway (vide infra).

The present conditions for catalytic enantioselective diacetoxylation reaction could also be extended to the substrate class of internal alkenes, which are beyond the scope of our earlier catalysts $\mathbf{4 b , c}$. While $\beta$-methylstyrene did not display any reactivity under the present standard catalytic conditions, cinnamic alcohol and its derivatives were found 


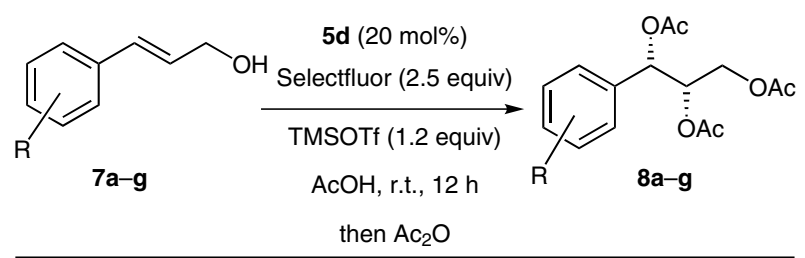<smiles>CC(=O)OC[C@H](OC(C)=O)[C@@H](OC(C)=O)c1ccccc1</smiles>

8a: $49 \%, 90: 10$ d.r., $95 \%$ ee $49 \%, 90: 10$ d.r., $88 \% e e^{c}$<smiles>CC(=O)OC[C@H](OC(C)=O)[C@H](OC(C)=O)c1ccccc1Cl</smiles>
8c: $65 \%, 88: 12$ d.r., $88 \% e e^{e}$<smiles>CC(=O)OC[C@H](OC(C)=O)[C@@H](OC(C)=O)c1cccc(F)c1</smiles>

8e: $42 \%, 80: 20$ d.r., $80 \%$ ee<smiles>COC[C@H](OC(C)=O)[C@H](OC(C)=O)c1ccccc1</smiles>

8b: $56 \%, 95: 5$ d.r., $86 \%$ ee<smiles>CC(=O)OC[C@H](OC(C)=O)[C@H](OC(C)=O)c1ccccc1Br</smiles>

8d: $59 \%, 92: 8$ d.r., $96 \%$ ee<smiles>CC(=O)OC[C@H](OC(C)=O)[C@@H](OC(C)=O)c1ccc(F)cc1</smiles>

8f: $44 \%, 97: 3$ d.r., $78 \%$ ee<smiles>CC(=O)OC[C@H](OC(C)=O)[C@@H](OC(C)=O)c1ccc(C(F)(F)F)cc1</smiles>

8 g: $65 \%, 80: 20$ d.r., $84 \% e e^{e}$

Scheme 5 Scope of the iodine(III)-catalyzed enantioselective diacetoxylation of styrenes. ${ }^{\mathrm{a}, \mathrm{b}} \mathrm{a}$ Isolated yield after purification. ${ }^{\mathrm{b}}$ Determination of ee was carried out by HPLC on chiral stationary phase. ${ }^{21}$ c From cinnamyl acetate $\mathbf{7 a} \mathbf{a}^{\prime}{ }^{\mathrm{d}}$ From cinnamyl methyl ether $\mathbf{7 b}$. ${ }^{\mathrm{e}}$ With $\mathbf{5 b}$ as catalyst.

to be suitable substrates (Scheme 5). This observation is reminiscent of the earlier report on stoichiometric reactivity $^{9}$ and appears to be the consequence of an electronic effect of the allylic oxygen. For example, cinnamyl alcohol (7a) gave the corresponding oxidation product 8a with a 90:10 diastereomeric ratio in favor of the like-product $\mathbf{8 a}$, which formed with $95 \%$ ee. The same product could be obtained from the acetoxylated alcohol leading to an identical product formation with $88 \%$ ee. This somewhat lower induction may be the result of the presence of a sterically more demanding acetoxy substituent retarding the face selection. The corresponding cinnamyl methyl ether led to a 95:5 diastereomeric ratio in favor of the like-product $\mathbf{8 b}$, which formed with $86 \%$ ee. From this observation, possible hydrogen bonding from the free $\mathrm{OH}$ in $\mathbf{8 a}$ appears not to

play an essential role in the reaction. Finally, substituted free cinnamyl alcohols $\mathbf{7 c -} \mathbf{g}$ gave the corresponding like-diacetoxylation products $\mathbf{8 c}-\mathbf{g}$ in good to very good diastereoselectivities and with 78-96\% ee.

While the crude product was usually directly transformed by treatment with acetic anhydride to furnish single diacetate products $\mathbf{8}$ in all cases as shown in Scheme 5, we also investigated again the initial formation of different dioxygenation products for cinnamyl methyl ether (7b) (Scheme 6). After direct workup, the crude reaction product was identified to consist of a mixture of the diacetoxylation product $\mathbf{8 b}$ in $7 \%$ and with $84 \%$ ee, together with $55 \%$ of the two hydroxylated products $9 \mathbf{a}$ and $\mathbf{9 b}$ in a 70:30 ratio. After separation of the two compounds and their conversion into $\mathbf{8 b}$ by acetoxylation with acetic anhydride, an identical $86 \%$ ee was determined for both samples. This outcome confirms a like-configuration for products $\mathbf{9 a , b}$ and suggests the dominance of a Woodward pathway in the cases of internal alkenes $\mathbf{7 a - g}$ and $\mathbf{7 a}$ '.

In addition, the observed like-configuration for product $\mathbf{8 b}$ is inconsistent with the potential involvement of a Prévost mechanism, as the underlying opening of the corresponding cationic dioxolanyl intermediate should generate the opposite diastereoisomer of an unlike-configuration.

As a result, it must be concluded that Prévost pathways are entirely absent in the present oxidative difunctionalization of styrenes. Instead, a direct reductive elimination of the iodine(III) moiety in intermediate $\mathbf{C}^{\prime}$ appears to be taking place (Figure 5). Such a process involves an intermolecular $\mathrm{S}_{\mathrm{N}} 2$-displacement $\mathbf{E}$ of the iodine(III) nucleofuge ${ }^{27}$

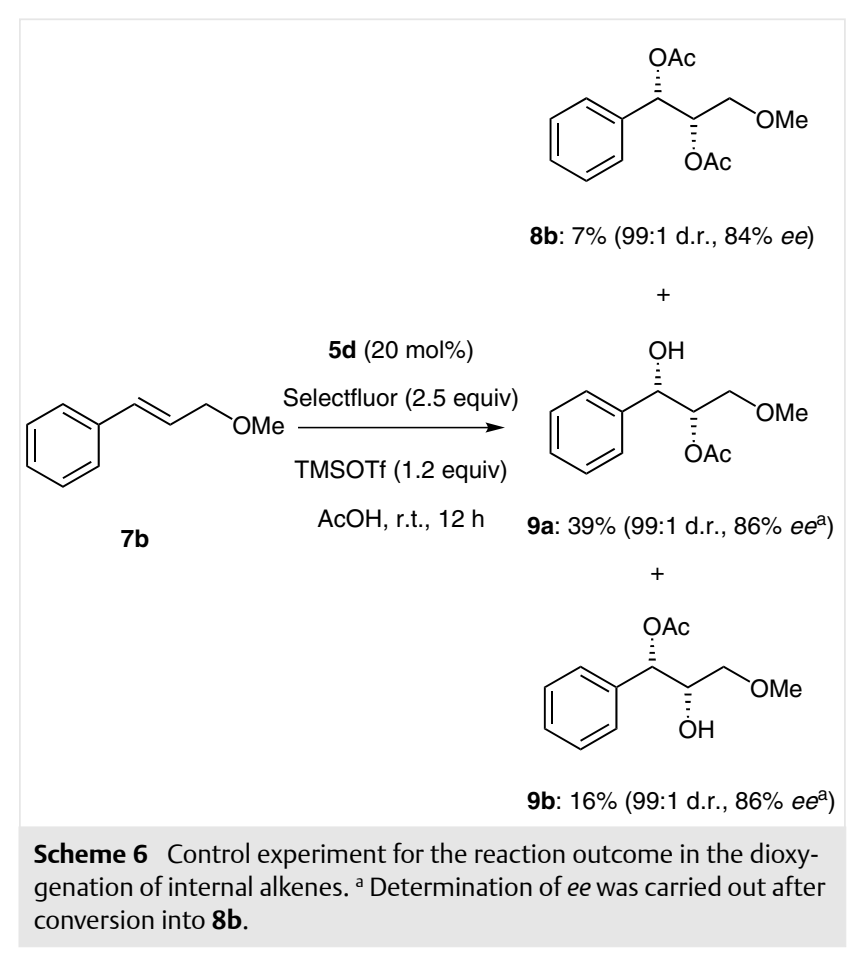


through acetate or acetic acid at stage $\mathbf{C}^{\prime}$, which competes with the intramolecular displacement that forms the dioxolonium intermediate $\mathbf{D}^{\prime}$. Such a direct nucleophilic substitution at the alkyl-iodine(III) group is in agreement with related investigation on ditosylation reactions.,7a,16d,28 In these cases, the tosyl group does not engage in an intramolecular iodine displacement leading to a stereochemical outcome that perfectly resembles the one from the present diacetoxylation. ${ }^{28}$

For steric reasons, such direct iodine for acetate exchange at stage $\mathbf{E}$ has a higher chance to proceed for styrene derivatives, where the $S_{N} 2$ reaction proceeds at a primary center $(\mathrm{R}=\mathrm{H})$. In contrast, for cinnamyl derivatives, the Woodward pathway is largely dominating. Since both path-

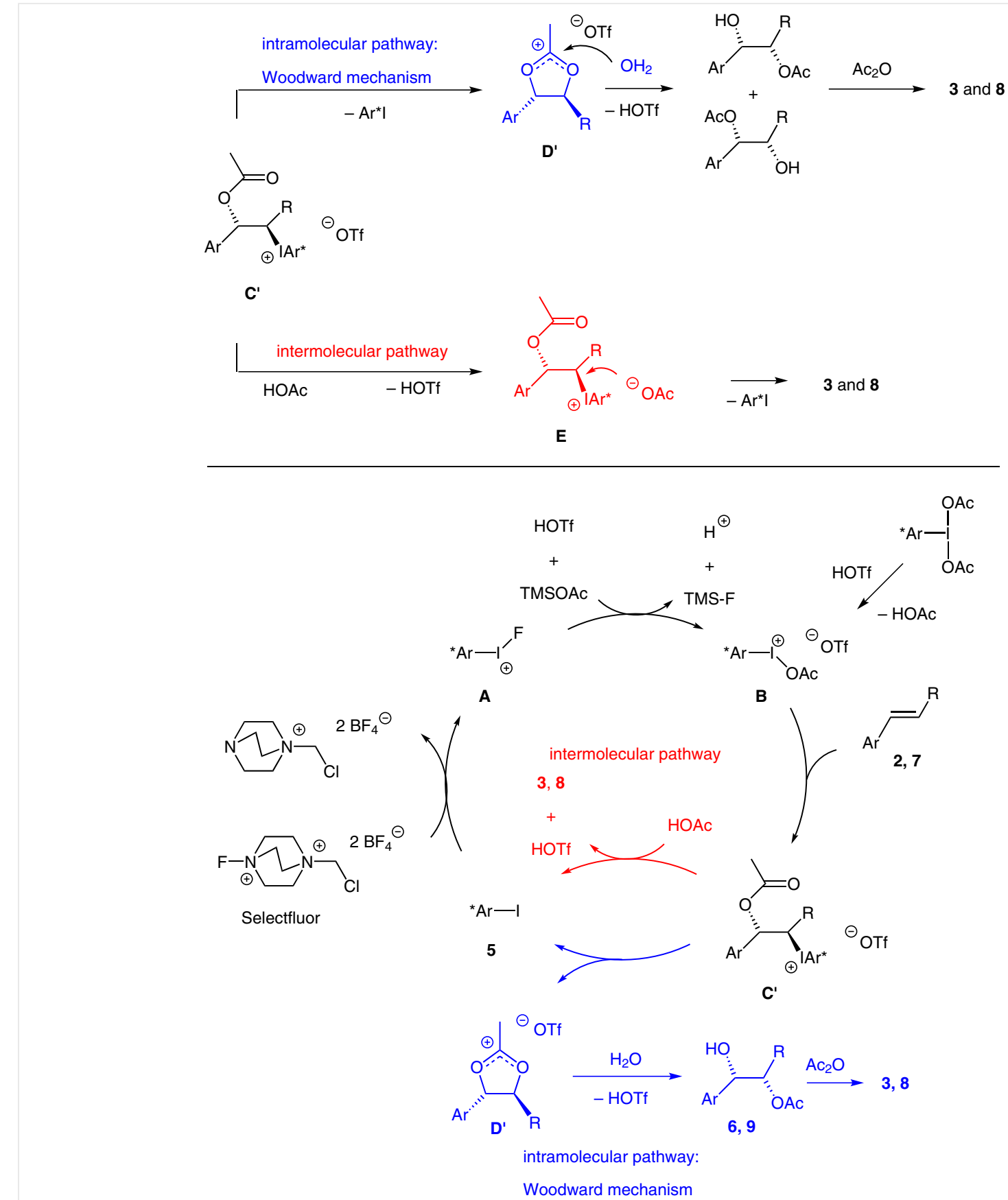

Figure 5 Mechanistic conclusion: Competing pathways in the enantioselective catalytic diacetoxylation of alkenes and overall catalytic cycle for diacetoxylation of terminal $(\mathrm{R}=\mathrm{H})$ and internal alkenes 
ways lead to stereochemically uniform products, the relative participation of each of the enantioconvergent pathway does not alter the overall enantiomeric excess of the product. Figure 5 displays the full catalytic cycle based on all data including control experiments and stereochemical conclusions.

In summary, we have developed a second protocol for an iodine(III)-catalyzed enantioselective vicinal dioxygenation of alkenes under intermolecular reaction control. The reaction proceeds under mild conditions, extends the substrate class to $\beta$-substituted styrenes and provides the corresponding oxidation products with up to $96 \%$ ee. The two successful realizations of catalytic dioxygenation with $\mathbf{4 b}, \mathbf{c}$ and now 5d should be instructive for the development of similar iodine(I/III)-catalyzed enantioselective difunctionalization reactions of alkenes. ${ }^{29}$

All solvents, reagents, and all deuterated solvents were purchased from Aldrich and Acros. Column chromatography was performed with silica gel Merck type $60(0.063-0.20 \mathrm{~mm})$. NMR spectra were recorded on a Bruker Avance $300 \mathrm{MHz}, 400 \mathrm{MHz}$, or $500 \mathrm{MHz}$ spectrometer, respectively. All chemical shifts in NMR experiments are reported in ppm downfield from TMS. The following calibrations were used: $\mathrm{CDCl}_{3} \delta=7.26$ and 77.16; DMSO- $d_{6} \delta=2.50$ and 39.52. MS (ESILCMS) experiments were performed using an Agilent 1100 HPLC with a Bruker micro-TOF instrument (ESI). Unless otherwise stated, a Supelco C8 ( $5 \mathrm{~cm} \times 4.6 \mathrm{~mm}, 5 \mu \mathrm{m}$ particles) column was used with a linear elution gradient from $100 \% \mathrm{H}_{2} \mathrm{O}\left(0.5 \% \mathrm{HCO}_{2} \mathrm{H}\right)$ to $100 \% \mathrm{MeCN}$ in $13 \mathrm{~min}$ at a flow rate of $0.5 \mathrm{~mL} / \mathrm{min}$. MS (EI) and HRMS experiments were performed on a Kratos MS 50 within the service departments at ICIQ. Melting points were determined with a Büchi Melting Point B540 apparatus. IR spectra were taken with a Bruker Alpha instrument in the solid state. Specific optical rotation values were measured with a Polarimeter JascoP1030 equipped with a $100 \mathrm{~mm}$ cell. HPLC measurements were carried out on a Knauer Wellchrome (injection valve A0258, pump K-100, solvent organizer K-1500, UV detector K-2600). The respective chiral stationary phase and exact conditions are specified for each individual compound within the compound characterization section. Diastereomeric ratios were determined by achiral gas chromatography on an Agilent Technologies 7890A gas chromatograph equipped with an Agilent J \& W HP-5 column.

Synthesis and availability of styrenes $\mathbf{2 a - q}$, diacetoxylation products $\mathbf{3 a}-\mathbf{q}$, and the corresponding free diols were reported previously. ${ }^{18}$ (E)-1-Phenyl-3-methoxypropene (7b), ${ }^{30}(E)$-3-(2-chlorophenyl)prop2-en-1-ol (7c), ${ }^{31 a}(E)-3$-(2-bromophenyl)prop-2-en-1-ol (7d), ${ }^{31 b}(E)-$ 3-(3-fluorophenyl)prop-2-en-1-ol (7e), ${ }^{31 \mathrm{c}} \quad$ (E)-3-(4-fluorophenyl)prop-2-en-1-ol (7f), ${ }^{31}$ (E)-3-(4-trifluoromethylphenyl)prop-2en-1-ol ( $\mathbf{7 g})^{31 \mathrm{e}}$ were synthesized according to a literature protocol. ${ }^{32}$ Products 8a,b were reported previously. ${ }^{33}$

\section{Diacetoxylation of Alkenes Catalyzed by Hypervalent Iodine Re- agents; General Procedure}

A Pyrex tube equipped with a stir bar was charged with the respective iodine(I)- or iodine(III)-compound $(0.040 \mathrm{mmol}, 20 \mathrm{~mol} \%)$ and $\mathrm{AcOH}(4 \mathrm{~mL})$. The addition of the respective alkene $(0.20 \mathrm{mmol}, 1.0$ equiv) was followed by subsequent addition of Selectfluor $(0.50$ mmol, 2.5 equiv) and TMSOTf ( $0.24 \mathrm{mmol}, 1.2$ equiv). The tube was sealed and the reaction mixture was stirred at r.t. for $12 \mathrm{~h}$. The reaction mixture was poured into a separating funnel containing $\mathrm{CH}_{2} \mathrm{Cl}_{2}$ and $\mathrm{H}_{2} \mathrm{O}$. The layers were separated and the aqueous phase was extracted with $\mathrm{CH}_{2} \mathrm{Cl}_{2}(3 \times)$. The combined organic layers were washed with $\mathrm{H}_{2} \mathrm{O}(1 \times)$ and brine $(1 \times)$. Drying the organic phase over $\mathrm{Na}_{2} \mathrm{SO}_{4}$ and filtration was followed by removal of the solvents under reduced pressure. The residue was dissolved in $\mathrm{CH}_{2} \mathrm{Cl}_{2}(0.35 \mathrm{~mL})$ and, depending on whether a styrene- or a cinnamyl alcohol derivative was used as the starting material, DMAP $(0.050-0.070 \mathrm{mmol}, 0.25-0.35$ equiv $)$, pyridine (0.50-0.70 mmol, 2.5-3.5 equiv), and $\mathrm{Ac}_{2} \mathrm{O}(0.50-0.70 \mathrm{mmol}$, 2.5-3.5 equiv) were added. After stirring at r.t. for $5 \mathrm{~h}$, aq $1 \mathrm{M} \mathrm{HCl}$ and $\mathrm{H}_{2} \mathrm{O}$ were added and the aqueous phase was extracted with $\mathrm{CH}_{2} \mathrm{Cl}_{2}(3$ $\times$ ). After drying over $\mathrm{Na}_{2} \mathrm{SO}_{4}$ and removing the solvent under reduced pressure, the crude product was purified by flash column chromatography on silica gel using hexane/EtOAc mixtures. In order to determine the enantiomeric excesses in the cases of styrene derivatives as starting materials, the pure product was dissolved in $\mathrm{MeOH}(0.1 \mathrm{M})$. Addition of $\mathrm{K}_{2} \mathrm{CO}_{3}$ (1.5 equiv) was followed by stirring at r.t. for $4 \mathrm{~h}$. $\mathrm{MeOH}$ was removed under reduced pressure after acidification with aq $1 \mathrm{M} \mathrm{HCl}$. Extraction of the aqueous layer with $\mathrm{CH}_{2} \mathrm{Cl}_{2}(3 \times)$, drying the combined organic layers over $\mathrm{Na}_{2} \mathrm{SO}_{4}$, and evaporation of the solvent yielded the corresponding diol, which was submitted to HPLC analysis. In the case of cinnamyl alcohol derived starting materials, enantiomeric excesses were determined at the stage of the acetoxylated products.

\section{(S)-1-Phenylethane-1,2-diol-1,2-diacetate (3a)}

Isolated yield: $29.4 \mathrm{mg}$ (66\%). HPLC-conditions for free diol: OD-H, hexane $/ i-\mathrm{PrOH}=95: 5,0.7 \mathrm{~mL} / \mathrm{min}, t_{\mathrm{R}}=24.9$ (minor), 27.3 (major): $80 \%$ ee.

\section{(S)-1-(4-Fluorophenyl)ethane-1,2-diol-1,2-diacetate (3b)}

Isolated yield: $26.4 \mathrm{mg}$ (55\%). HPLC-conditions for free diol: OD-H, hexane $/ i-\mathrm{PrOH}=95: 5,1 \mathrm{~mL} / \mathrm{min}, t_{\mathrm{R}}=17.1$ (minor), 18.5 (major): $74 \%$ ee.

\section{(S)-1-(4-Chlorophenyl)ethane-1,2-diol-1,2-diacetate (3c)}

Isolated yield: $32 \mathrm{mg}$ (62\%). HPLC-conditions for free diol: OD-H, hexane $/ i-\mathrm{PrOH}=95: 5,1 \mathrm{~mL} / \mathrm{min}, t_{\mathrm{R}}=18.2$ (minor), 19.8 (major): $74 \%$ ee.

\section{(S)-1-(4-Bromophenyl)ethane-1,2-diol-1,2-diacetate (3d)}

Isolated yield: $55.4 \mathrm{mg}$ (92\%). HPLC-conditions for free diol: OD-H, hexane $/ i-\mathrm{PrOH}=95: 5,0.5 \mathrm{~mL} / \mathrm{min}, t_{\mathrm{R}}=39.9$ (minor), 43.2 (major): $64 \%$ ee.

(S)-1-(4-Trifluoromethylphenyl)ethane-1,2-diol-1,2-diacetate (3e) Isolated yield: $35.4 \mathrm{mg}$ (61\%). HPLC-conditions for free diol: OD-H, hexane $/ i$-PrOH $=95: 5,0.5 \mathrm{~mL} / \mathrm{min}, t_{\mathrm{R}}=34.8$ (minor), 36.5 (major): $68 \%$ ee.

\section{(S)-4-(Phthaloylmethylenephenyl)ethane-1,2-diol-1,2-diacetate} (3f)

Isolated yield: $56.4 \mathrm{mg}(74 \%)$. HPLC-conditions for free diol: IA, hexane $/ i-\mathrm{PrOH}=93: 7,1 \mathrm{~mL} / \mathrm{min}, t_{\mathrm{R}}=90.3$ (major), 101.6 (minor): $86 \%$ ee.

\section{(S)-1-(4-tert-Butylphenyl)ethane-1,2-diol-1,2-diacetate (3g)}

Isolated yield: $30.6 \mathrm{mg}$ (55\%). HPLC-conditions for free diol: OD, hexane $/ i-\mathrm{PrOH}=98: 2,0.8 \mathrm{~mL} / \mathrm{min}, t_{\mathrm{R}}=48.7$ (minor), 52.6 (major): 68 ee. 
(S)-1-(3-Trifluoromethylphenyl)ethane-1,2-diol-1,2-diacetate (3h) Isolated yield: $41.3 \mathrm{mg}$ (71\%). HPLC-conditions for free diol: OD-H, hexane $/ i-\mathrm{PrOH}=95: 5,0.7 \mathrm{~mL} / \mathrm{min}, t_{\mathrm{R}}=19.8$ (minor), 22.3 (major): 74 ee.

\section{(S)-1-(3-Fluorophenyl)ethane-1,2-diol-1,2-diacetate (3i)}

Isolated yield: $34.6 \mathrm{mg}$ (72\%). HPLC-conditions for free diol: OD-H, hexane $/ i-\mathrm{PrOH}=95: 5,1 \mathrm{~mL} / \mathrm{min}, t_{\mathrm{R}}=16.0$ (minor), 17.7 (major): $82 \%$ ee.

\section{(S)-1-(2-Chlorophenyl)ethane-1,2-diol-1,2-diacetate (3j)}

Isolated yield: $37.5 \mathrm{mg}$ (73\%). HPLC-conditions for free diol: OD-H, hexane $/ i-\mathrm{PrOH}=95: 5,1 \mathrm{~mL} / \mathrm{min}, t_{\mathrm{R}}=13.4$ (minor), 17.5 (major): $88 \%$ ee.

\section{(S)-1-(2-Fluorophenyl)ethane-1,2-diol-1,2-diacetate (3k)}

Isolated yield: $31 \mathrm{mg}$ (65\%). HPLC-conditions for free diol: OD-H, hexane $/ i-\mathrm{PrOH}=95: 5,1 \mathrm{~mL} / \mathrm{min}, t_{\mathrm{R}}=12.7$ (minor), 15.2 (major): $82 \%$ ee.

\section{(S)-1-(2-Bromophenyl)ethane-1,2-diol-1,2-diacetate (31)}

Isolated yield: $42.2 \mathrm{mg}$ (70\%). HPLC-conditions for free diol: OD-H, hexane $/ i-\mathrm{PrOH}=95: 5,0.7 \mathrm{~mL} / \mathrm{min}, t_{\mathrm{R}}=21.3$ (minor), 27.9 (major): $86 \%$ ee.

\section{(S)-1-(2-Methylphenyl)ethane-1,2-diol-1,2-diacetate (3m)}

Isolated yield: $30.2 \mathrm{mg}$ (64\%). HPLC-conditions for free diol: OD-H, hexane $/ i-\mathrm{PrOH}=95: 5,0.7 \mathrm{~mL} / \mathrm{min}, t_{\mathrm{R}}=21.9$ (minor), 27.9 (major): $74 \%$ ee.

(S)-1-(3-Chloro-2-fluorophenyl)ethane-1,2-diol-1,2-diacetate (3n) Isolated yield: $46.7 \mathrm{mg}$ (85\%). HPLC-conditions for free diol: OD-H, hexane $/ i-\mathrm{PrOH}=95: 5,0.7 \mathrm{~mL} / \mathrm{min}, t_{\mathrm{R}}=20.0$ (minor), 25.8 (major): $64 \%$ ee.

(S)-1-(4-Bromo-2-fluorophenyl)ethane-1,2-diol-1,2-diacetate (3o) Isolated yield: $53 \mathrm{mg}$ (83\%). HPLC-conditions for free diol: OD-H, hexane $/ i-\mathrm{PrOH}=95: 5,0.7 \mathrm{~mL} / \mathrm{min}, t_{\mathrm{R}}=20.1$ (minor), 22.8 (major): $62 \%$ ee.

\section{(S)-1-(3,5-Dimethylphenyl)ethane-1,2-diol-1,2-diacetate (3p)}

Isolated yield: $31 \mathrm{mg}$ (62\%). HPLC-conditions for free diol: OD-H, hexane $/ i-\mathrm{PrOH}=95: 5,0.7 \mathrm{~mL} / \mathrm{min}, t_{\mathrm{R}}=19.2$ (minor), 22.3 (major): $62 \%$ ee.

\section{(S)-1-(2-Naphthyl)ethane-1,2-diol-1,2-diacetate (3q)}

Isolated yield: $34.3 \mathrm{mg}$ (63\%). HPLC-conditions for free diol: OD-H, hexane $/ i-\mathrm{PrOH}=90: 10,0.95 \mathrm{~mL} / \mathrm{min}, t_{\mathrm{R}}=14.6$ (minor), 17.7 (major): $64 \%$ ee.

(1S,2S)-1,2,3-Propanetriol-1-phenyl-1,2,3-triacetate (8a) Isolated yield: $28.8 \mathrm{mg}$ (49\%). HPLC-conditions: OJ, hexane $/ i-\mathrm{PrOH}=$ $85: 15,1.0 \mathrm{~mL} / \mathrm{min}, t_{\mathrm{R}}=23.2$ (major), 32.9 (minor): $88 \%$ ee.

(1S,2S)-3-Methoxy-1-phenyl-1,2-propanediol-1,2-diacetate (8b) Isolated yield: $30 \mathrm{mg}$ (56\%). HPLC-conditions: IC, hexane $/ i-\mathrm{PrOH}=$ 95:5, $0.5 \mathrm{~mL} / \mathrm{min}, t_{\mathrm{R}}=23.7$ (minor), 27.3 (major): $86 \%$ ee.
$(R, R)$-1,3-Bis[1-(2-adamantoxycarbonyl)ethoxy]-2-iodobenzene (5c)

According to the procedure of Breit, ${ }^{34}$ a solution of $\mathrm{N}, \mathrm{N}$-dicyclohexylcarbodiimide (706 mg, $3.42 \mathrm{mmol}, 2.60$ equiv) in $\mathrm{CH}_{2} \mathrm{Cl}_{2}(4.4 \mathrm{~mL})$ was added to a suspension of $\left(2 R, 2^{\prime} R\right)-2,2^{\prime}$-(2-iodo-1,3-phenylene)bis(oxy)dipropanoic acid (500 mg, $1.32 \mathrm{mmol}$ ), 2-adamantanol ( $881 \mathrm{mg}, 5.79 \mathrm{mmol}, 4.40$ equiv), and DMAP (106 mg, $0.870 \mathrm{mmol}$, 0.660 equiv) in $\mathrm{CH}_{2} \mathrm{Cl}_{2}(6.6 \mathrm{~mL})$ at $0{ }^{\circ} \mathrm{C}$. Stirring was continued for 12 $\mathrm{h}$, while the reaction mixture was allowed to warm to r.t. slowly. A small amount of silica gel was added to the reaction mixture, the solvent was removed under reduced pressure, and the crude product was submitted to flash column chromatography using hexane/EtOAc (12:1) as eluent. Washing the obtained compound with pentane yielded the pure product (604 $\mathrm{mg}, 71 \%$ ) as a white crystalline solid; mp $136{ }^{\circ} \mathrm{C} ;[\alpha]_{\mathrm{D}}{ }^{25}-39.1\left(c=0.115, \mathrm{CHCl}_{3}\right)$.

IR (ATR): 2989, 2903, 2852, 2673, 2119, 1736, 1719, 1587, 1458, 1374, 1344, 1277, 1252, 1217, 1200, 1182, 1135, 1098, 1067, 1041, 1016, $977,964,933,903,860,817,798,764,753,703,675,647,626,607$, $575,508,456,412 \mathrm{~cm}^{-1}$.

${ }^{1} \mathrm{H} \mathrm{NMR}\left(400 \mathrm{MHz}, \mathrm{CDCl}_{3}\right): \delta=1.37-2.01(\mathrm{~m}, 28 \mathrm{H}), 1.71(\mathrm{~d}, J=6.5 \mathrm{~Hz}$, $6 \mathrm{H}), 4.80$ (q, $J=4.6 \mathrm{~Hz}, 2 \mathrm{H}), 4.94-4.97(\mathrm{~m}, 2 \mathrm{H}), 6.39$ (d, $J=8.6 \mathrm{~Hz}, 2$ $\mathrm{H}), 7.10(\mathrm{t}, J=8.2 \mathrm{~Hz}, 1 \mathrm{H})$.

${ }^{13} \mathrm{C}$ NMR $\left(100 \mathrm{MHz}, \mathrm{CDCl}_{3}\right): \delta=18.8,27.0,27.2,31.6,31.8,31.8,32.0$, 36.3, 36.4, 37.4, 74.4, 78.3, 80.6, 106.7, 129.5, 158.4, 171.2.

HRMS: $m / z$ calcd for $\mathrm{C}_{32} \mathrm{H}_{41} \mathrm{INaO}_{6}{ }^{+}$: 671.1840; found: 671.1846 .

\section{$(R, R)$-1,3-Bis[1-(1-adamantoxycarbonyl)ethoxy]-2-iodobenzene} (5d)

According to the procedure described above for compound $\mathbf{5 c},{ }^{21}$ the title compound was obtained as a white crystalline solid (76\%); mp $153^{\circ} \mathrm{C} ;[\alpha]_{\mathrm{D}}^{25}-27.9\left(c=0.1, \mathrm{CHCl}_{3}\right)$.

IR (ATR): 2985, 2907, 2852, 2117, 1746, 1586, 1458, 1374, 1349, 1315 , $1288,1250,1201,1180,1126,1101,1069,1046,1021,966,940,916$, 899, 876, 831, 761, 752, 725, 701, 642, 606, 589, 525, 467, 453, 407 $\mathrm{cm}^{-1}$.

${ }^{1} \mathrm{H}$ NMR $\left(500 \mathrm{MHz}, \mathrm{CDCl}_{3}\right): \delta=1.62-1.64(\mathrm{~m}, 12 \mathrm{H}), 1.66(\mathrm{~d}, J=6.8 \mathrm{~Hz}$, $6 \mathrm{H}), 2.03-2.09(\mathrm{~m}, 12 \mathrm{H}), 2.12-2.16(\mathrm{~m}, 6 \mathrm{H}), 4.63(\mathrm{q}, J=6.5 \mathrm{~Hz}, 2 \mathrm{H})$, $6.37(\mathrm{~d}, J=8.2 \mathrm{~Hz}, 2 \mathrm{H}), 7.12(\mathrm{t}, J=7.9 \mathrm{~Hz}, 1 \mathrm{H})$.

${ }^{13} \mathrm{C}$ NMR $\left(125 \mathrm{MHz}, \mathrm{CDCl}_{3}\right): \delta=18.7,31.0,36.2,41.3,74.6,80.6,82.1$, 106.7, 129.3, 158.5, 170.7 .

HRMS: $m / z$ calcd for $\mathrm{C}_{32} \mathrm{H}_{41} \mathrm{INaO}_{6}{ }^{+}$: 671.1840; found: 671.1840 .

(1S,2S)-1,2,3-Propanetriol-1-(2-chlorophenyl)-1,2,3-triacetate (8c) Synthesized according to the general procedure; colorless oil; isolated yield: $43 \mathrm{mg}$ (65\%). HPLC conditions: OJ, hexane $/ i-\mathrm{PrOH}=85: 15,0.5$ $\mathrm{mL} / \mathrm{min}, t_{\mathrm{R}}=35.3$ (major), 45.7 (minor).

IR (ATR): 2958, 2926, 2854, 1742, 1475, 1442, 1370, 1209, 1126, 1042, $960,865,760,741,710,689,602,568,546,475,459,415 \mathrm{~cm}^{-1}$.

${ }^{1} \mathrm{H}$ NMR $\left(500 \mathrm{MHz}, \mathrm{CDCl}_{3}\right): \delta=1.99(\mathrm{~s}, 3 \mathrm{H}), 2.05(\mathrm{~s}, 3 \mathrm{H}), 2.12(\mathrm{~s}, 3 \mathrm{H})$, 4.04 (dd, $J=11.8,6.6 \mathrm{~Hz}, 1 \mathrm{H}), 4.27(\mathrm{dd}, J=11.8,4.5 \mathrm{~Hz}, 1 \mathrm{H}), 5.55$ (ddd, $J=6.6,5.3,4.5 \mathrm{~Hz}, 1 \mathrm{H}), 6.41(\mathrm{~d}, J=5.3 \mathrm{~Hz}, 1 \mathrm{H}), 7.23-7.29(\mathrm{~m}, 2$ $\mathrm{H}), 7.35-7.40$ ( $\mathrm{m}, 2 \mathrm{H}$ ).

${ }^{13} \mathrm{C}$ NMR $\left(125 \mathrm{MHz}, \mathrm{CDCl}_{3}\right): \delta=20.8,20.8,21.0,62.2,70.6,71.1,127.1$, $128.3,129.9,130.0,133.0,134.1,169.5,169.9,170.6$.

HRMS: $m / z$ calcd for $\mathrm{C}_{15} \mathrm{H}_{17} \mathrm{ClNaO}_{6}{ }^{+}: 351.0606$; found: 351.0602 . 


\section{(1S,2S)-1,2,3-Propanetriol-1-(2-bromophenyl)-1,2,3-triacetate (8d)}

Synthesized according to the general procedure; colorless oil; isolated yield: $44 \mathrm{mg}$ (59\%). HPLC conditions: IB, hexane/ $i-\mathrm{PrOH}=95: 5,0.3$ $\mathrm{mL} / \mathrm{min}, t_{\mathrm{R}}=28.6$ (major), 30.3 (minor).

IR (ATR): 3423, 2961, 1744, 1470, 1438, 1370, 1210, 1122, 1043, 1021, $961,865,759,737,686,603,567,545,470,453 \mathrm{~cm}^{-1}$.

${ }^{1} \mathrm{H}$ NMR (400 MHz, $\left.\mathrm{CDCl}_{3}\right): \delta=1.99(\mathrm{~s}, 3 \mathrm{H}), 2.05$ (s, $\left.3 \mathrm{H}\right), 2.12(\mathrm{~s}, 3 \mathrm{H})$, $4.07(\mathrm{dd}, J=11.8,6.6 \mathrm{~Hz}, 1 \mathrm{H}), 4.27(\mathrm{dd}, J=11.8,5.0 \mathrm{~Hz}, 1 \mathrm{H}), 5.55$ (ddd, $J=6.7,5.0,5.0 \mathrm{~Hz}, 1 \mathrm{H}), 6.37$ (d, $J=5.0 \mathrm{~Hz}, 1 \mathrm{H}), 7.15-7.19(\mathrm{~m}, 1$ H), 7.28-7.32 (m, $1 \mathrm{H}), 7.36-7.39$ ( $\mathrm{m}, 1 \mathrm{H}), 7.54-7.56$ ( $\mathrm{m}, 1 \mathrm{H})$.

${ }^{13} \mathrm{C} \mathrm{NMR}\left(100 \mathrm{MHz}, \mathrm{CDCl}_{3}\right): \delta=20.7,20.9,20.9,62.2,71.1,72.8,122.9$, 127.6, 128.6, 130.2, 133.3, 135.8, 169.5, 169.8, 170.6.

HRMS: $m / z$ calcd for $\mathrm{C}_{15} \mathrm{H}_{17} \mathrm{BrNaO}_{6}{ }^{+}$: 395.0101; found: 395.0110 .

(1S,2S)-1,2,3-Propanetriol-1-(3-fluorophenyl)-1,2,3-triacetate (8e) Synthesized according to the general procedure; colorless oil; isolated yield of a 4:1 diastereomeric mixture: $26.2 \mathrm{mg}$ (42\%). HPLC conditions: IB, hexane/i-PrOH 0 95:5, $0.5 \mathrm{~mL} / \mathrm{min}, t_{\mathrm{R}}=16.0$ (minor), 18.3 (major).

IR (ATR): 3441, 2962, 1742, 1617, 1593, 1490, 1450, 1371, 1210, 1145 , 1079, 1044, 969, 947, 912, 872, 792, 768, 732, 702, 648, 602, 522, 485, $448,409 \mathrm{~cm}^{-1}$.

${ }^{1} \mathrm{H}$ NMR (400 MHz, $\left.\mathrm{CDCl}_{3}\right): \delta=2.05(\mathrm{~s}, 3 \mathrm{H}), 2.05(\mathrm{~s}, 3 \mathrm{H}), 2.10(\mathrm{~s}, 3 \mathrm{H})$, 3.82 (dd, $J=12.1,5.7 \mathrm{~Hz}, 1 \mathrm{H}$ ), 4.28 (dd, $J=12.1,4.0 \mathrm{~Hz}, 1 \mathrm{H}$ ), 5.39 (ddd, $J=6.6,5.7,3.9 \mathrm{~Hz}, 1 \mathrm{H}), 5.94(\mathrm{~d}, J=6.6 \mathrm{~Hz}, 1 \mathrm{H}), 6.99-7.09(\mathrm{~m}, 2$ H), 7.12-7.14 (m, $1 \mathrm{H}), 7.30-7.35(\mathrm{~m}, 1 \mathrm{H})$.

${ }^{13} \mathrm{C}$ NMR $\left(100 \mathrm{MHz}, \mathrm{CDCl}_{3}\right): \delta=20.8,20.8,21.0,62.1,72.2,73.3(\mathrm{~d}, J=$ $1.8 \mathrm{~Hz}$ ), 114.3 (d, $J=23.0 \mathrm{~Hz}), 116.0$ (d, $J=20.0 \mathrm{~Hz}), 122.9$ (d, $J=3.1$ $\mathrm{Hz}), 130.5(\mathrm{~d}, J=8.3 \mathrm{~Hz}), 138.7(\mathrm{~d}, J=7.3 \mathrm{~Hz}), 163.0(\mathrm{~d}, J=246.9 \mathrm{~Hz})$, 169.8, 170.0, 170.5 .

${ }^{19} \mathrm{~F}$ NMR $\left(282 \mathrm{MHz}, \mathrm{CDCl}_{3}\right): \delta=-112.1$.

HRMS: $m / z$ calcd for $\mathrm{C}_{15} \mathrm{H}_{17} \mathrm{FNaO}_{6}^{+}$: 335.0901; found: 335.0912 .

\section{(1S,2S)-1,2,3-Propanetriol-1-(4-fluorophenyl)-1,2,3-triacetate (8f)}

Synthesized according to the general procedure; white solid; mp 103 ${ }^{\circ} \mathrm{C}$; isolated yield: $27.5 \mathrm{mg}$ (44\%). HPLC conditions: IB, hexane $/ i$-PrOH = 95:5, $0.5 \mathrm{~mL} / \mathrm{min}, t_{\mathrm{R}}=16.6$ (minor), 19.0 (major).

IR (ATR): 2959, 1740, 1607, 1512, 1434, 1371, 1211, 1160, 1044, 961, $837,788,730,689,647,603,544,501,435 \mathrm{~cm}^{-1}$.

${ }^{1} \mathrm{H} \mathrm{NMR}\left(400 \mathrm{MHz}, \mathrm{CDCl}_{3}\right): \delta=2.05(\mathrm{~s}, 3 \mathrm{H}), 2.05(\mathrm{~s}, 3 \mathrm{H}), 2.08(\mathrm{~s}, 3 \mathrm{H})$, $3.80(\mathrm{dd}, J=12.1,5.8 \mathrm{~Hz}, 1 \mathrm{H}), 4.26(\mathrm{dd}, J=12.1,3.8 \mathrm{~Hz}, 1 \mathrm{H}), 5.40$ (ddd, $J=7.1,5.7,3.7 \mathrm{~Hz}, 1 \mathrm{H}), 5.94(\mathrm{~d}, J=7.1 \mathrm{~Hz}, 1 \mathrm{H}), 7.02-7.08$ (m, 2 $\mathrm{H}), 7.32-7.37$ (m, $2 \mathrm{H})$.

${ }^{13} \mathrm{C}$ NMR $\left(100 \mathrm{MHz}, \mathrm{CDCl}_{3}\right): \delta=20.8,20.9,21.1,62.2,72.3,73.3,115.9$ $(\mathrm{d}, J=21.7 \mathrm{~Hz}), 129.2$ (d, $J=8.4 \mathrm{~Hz}), 132.0$ (d, $J=3.3 \mathrm{~Hz}), 163.0$ (d, $J=$ $248.4 \mathrm{~Hz}), 169.8,170.1,170.5$.

${ }^{19} \mathrm{~F} \mathrm{NMR}\left(282 \mathrm{MHz}, \mathrm{CDCl}_{3}\right): \delta=-112.5$.

HRMS: $m / z$ calcd for $\mathrm{C}_{15} \mathrm{H}_{17} \mathrm{FNaO}_{6}^{+}$: 335.0901; found: 335.0900 .

(1S,2S)-1,2,3-Propanetriol-1-(4-trifluoromethylphenyl)-1,2,3-triacetate $(8 \mathrm{~g})$

Synthesized according to the general procedure; white solid; isolated yield of a 4:1 diastereomeric mixture: $47 \mathrm{mg}$ (65\%). HPLC conditions: $\mathrm{IB}$, hexane $/ i-\mathrm{PrOH}=95: 5,0.5 \mathrm{~mL} / \mathrm{min}, t_{\mathrm{R}}=16.3$ (minor), 26.8 (major).
IR (ATR): 2958, 1742, 1622, 1422, 1372, 1324, 1212, 1164, 1122, 1066 , $1044,1017,962,839,765,749,697,602,531,454,432 \mathrm{~cm}^{-1}$.

${ }^{1} \mathrm{H}$ NMR (400 MHz, $\left.\mathrm{CDCl}_{3}\right): \delta=2.04(\mathrm{~s}, 3 \mathrm{H}), 2.04(\mathrm{~s}, 3 \mathrm{H}), 2.11(\mathrm{~s}, 3 \mathrm{H})$, $3.82(\mathrm{dd}, J=12.2,5.7 \mathrm{~Hz}, 1 \mathrm{H}), 4.30(\mathrm{dd}, J=12.2,4.2 \mathrm{~Hz}, 1 \mathrm{H}), 5.42$ (ddd, $J=6.5,5.8,4.1 \mathrm{~Hz}, 1 \mathrm{H}), 6.00$ (d, $J=6.6 \mathrm{~Hz}, 1 \mathrm{H}), 7.47-7.49$ (m, 2 $\mathrm{H}), 7.61-7.63(\mathrm{~m}, 2 \mathrm{H})$.

${ }^{13} \mathrm{C}$ NMR $\left(100 \mathrm{MHz}, \mathrm{CDCl}_{3}\right): \delta=20.8,20.8,21.0,62.0,72.0,73.3,123.9$ $(\mathrm{q}, J=272.6 \mathrm{~Hz}), 125.8(\mathrm{q}, J=3.8 \mathrm{~Hz}), 127.6,131.2(\mathrm{q}, J=32.8 \mathrm{~Hz})$, $140.2(\mathrm{q}, J=1.3 \mathrm{~Hz}), 169.7,169.9,170.5$.

${ }^{19} \mathrm{~F}$ NMR $\left(282 \mathrm{MHz}, \mathrm{CDCl}_{3}\right): \delta=-62.9$.

HRMS: $m / z$ calcd for $\mathrm{C}_{16} \mathrm{H}_{17} \mathrm{~F}_{3} \mathrm{NaO}_{6}{ }^{+}$: 385.0869 ; found: 385.0876 .

(1S,2S)-3-Methoxy-1-phenyl-1,2-propanediol-2-acetate (9a) and (1S,2S)-3-Methoxy-1-phenyl-1,2-propanediol-1-acetate (9b)

These compounds were synthesized from $\mathbf{7 b}$ according to the general procedure, but without acetoxylation using $\mathrm{Ac}_{2} \mathrm{O}$. Separation by column chromatography from the corresponding diacetate $\mathbf{8 b}$ afforded the pure compounds as colorless liquids; combined isolated yield: $27.8 \mathrm{mg}$ (55\%).

IR (ATR, both regioisomers): 3455, 3033, 2927, 1737, 1495, 1453, 1372, 1231, 1197, 1127, 1081, 1025, 985, 952, 916, 871, 850, 762, $732,701,622,540,495,448 \mathrm{~cm}^{-1}$.

\section{Major Regioisomer}

${ }^{1} \mathrm{H}$ NMR (400 MHz, $\mathrm{CDCl}_{3}$ ): $\delta=2.12(\mathrm{~s}, 3 \mathrm{H}), 2.33$ (br s, $1 \mathrm{H}$ ), 3.17 (dd, $J=9.8,5.6 \mathrm{~Hz}, 1 \mathrm{H}), 3.30-3.34(\mathrm{~m}, 1 \mathrm{H}), 3.31(\mathrm{~s}, 3 \mathrm{H}), 4.00$ (ddd, $J=7.3$, 5.6, $3.3 \mathrm{~Hz}, 1 \mathrm{H}), 5.84$ (d, J = 7.5 Hz, $1 \mathrm{H}), 7.28-7.40$ (m, $5 \mathrm{H})$.

${ }^{13} \mathrm{C}$ NMR $\left(100 \mathrm{MHz}, \mathrm{CDCl}_{3}\right): \delta=21.3,59.3,72.8,73.3,76.8,127.3$, 128.6, 128.7, 137.5, 170.4.

\section{Minor Regioisomer}

${ }^{1} \mathrm{H} \mathrm{NMR}\left(400 \mathrm{MHz}, \mathrm{CDCl}_{3}\right.$ ): $\delta=2.08$ (s, $3 \mathrm{H}$ ), 2.33 (br s, $1 \mathrm{H}$ ), 3.33 (s, 3 $\mathrm{H}), 3.38(\mathrm{dd}, J=10.8,4.1 \mathrm{~Hz}, 1 \mathrm{H}), 3.55(\mathrm{dd}, J=10.7,4.1 \mathrm{~Hz}, 1 \mathrm{H}), 5.00$ (d, $J=5.9 \mathrm{~Hz}, 1 \mathrm{H}$ ), 5.14 (ddd, $J=5.7,4.4,3.8 \mathrm{~Hz}, 1 \mathrm{H}), 7.28-7.40$ (m, 5 $\mathrm{H})$.

${ }^{13} \mathrm{C}$ NMR $\left(100 \mathrm{MHz}, \mathrm{CDCl}_{3}\right): \delta=21.2,59.5,71.7,73.7,75.9,126.7$, 128.3, 128.7, 140.2, 170.8.

HRMS: $m / z$ (both regiosisomers) calcd for $\mathrm{C}_{12} \mathrm{H}_{16} \mathrm{NaO}_{4}{ }^{+}: 247.0946$; found: 247.0941 .

\section{Acknowledgment}

Financial support for this project was provided from the Spanish Ministry for Economy and Competitiveness (CTQ2011-25027 grant to K. M., and Severo Ochoa Excellence Accreditation 2014-2018 to ICIQ, SEV-2013-0319) and the Deutsche Forschungsgemeinschaft (WO 1924/1-1). The authors thank Eduardo Escudero-Adán (ICIQ) for the $\mathrm{X}$-ray structural analyses.

\section{Supporting Information}

Supporting information for this article is available online at http://dx.doi.org/10.1055/s-0035-1561313.

\section{References}

(1) Present address: Dr. T. H. Wöste, Convertec GmbH, Heideweg 24, 77880 Sasbach, Germany. 
(2) (a) McDonald, R. I.; Liu, G.; Stahl, S. S. Chem. Rev. 2011, 111, 2981. (b) Jacques, B.; Muñiz, K. In Catalyzed Carbon-Heteroatom Bond Formation; Yudin, A., Ed.; Wiley-VCH: Weinheim, 2010, 119-135. (c) Cardona, F.; Goti, A. Nat. Chem. 2009, 1, 269. (d) Jensen, K. H.; Sigman, M. S. Org. Biomol. Chem. 2008, 6, 4083. (e) Wolfe, J. P. Synlett 2008, 2913.

(3) (a) Kolb, H. C.; VanNieuwenhze, M. S.; Sharpless, K. B. Chem. Rev. 1994, 94, 2483. (b) Zaitsev, A. B.; Adolfsson, H. Synthesis 2006, 1725. (c) Muñiz, K. Chem. Soc. Rev. 2004, 33, 166. (d) Donohoe, T. J.; Callens, C. K. A.; Flores, A.; Lacy, A. R.; Rathi, A. H. Chem. Eur. J. 2011, 17, 58.

(4) (a) Zhdankin, V. V. Hypervalent Iodine Chemistry Preparation, Structure and Synthetic Applications of Polyvalent Iodine Compounds; Wiley: Chichester, 2013. (b) Stang, P. J.; Zhdankin, V. V. Chem. Rev. 1996, 96, 1123. (c) Zhdankin, V. V.; Stang, P. J. Chem. Rev. 2002, 102, 2523. (d) Zhdankin, V. V.; Stang, P. J. Chem. Rev. 2008, 108, 5299.

(5) (a) Uyanik, M.; Ishihara, K. J. Synth. Org. Chem. Jpn. 2012, 70, 1116. (b) Singh, F. V.; Wirth, T. Chem. Asian J. 2014, 9, 950. (c) Romero, R. M.; Wöste, T. H.; Muñiz, K. Chem. Asian J. 2014, 9, 972. (d) Berthiol, F. Synthesis 2015, 47, 587.

(6) Koser, G. F. Top. Curr. Chem. 2003, 208, 137.

(7) (a) Hirt, U. H.; Spingler, B.; Wirth, T. J. Org. Chem. 1998, 63, 7674. (b) Wirth, T.; Hirt, U. H. Tetrahedron: Asymmetry 1997, 8 , 23. (c) Hirt, U. H.; Schuster, M. F. H.; French, A. N.; Wiest, O. G.; Wirth, T. Eur. J. Org. Chem. 2001, 1569. (d) Boye, A. C.; Meyer, D.; Ingison, C. K.; French, A. N.; Wirth, T. Org. Lett. 2003, 5, 2157.

(8) (a) Uyanik, M.; Yasui, T.; Ishihara, K. Angew. Chem. Int. Ed. 2010 , 49, 2175. (b) Uyanik, M.; Yasui, T.; Ishihara, K. Tetrahedron 2010, 66, 5841. (c) See also: Fujita, M.; Yoshida, Y.; Miyata, K.; Wakisaka, A.; Sugimura, T. Angew. Chem. Int. Ed. 2010, 49, 7068. (d) Fujita, M.; Okuno, S.; Lee, H. J.; Sugimura, T.; Okuyama, T. Tetrahedron Lett. 2007, 48, 8691. (e) Fujita, M.; Ookubo, Y.; Sugimura, T. Tetrahedron Lett. 2009, 50, 1298.

(9) Fujita, M.; Wakita, M.; Sugimura, T. Chem. Commun. 2011, 47, 3983.

(10) (a) Röben, C.; Souto, J. A.; González, Y.; Lishchynskyi, A.; Muñiz, K. Angew. Chem. Int. Ed. 2011, 50, 9478. (b) Souto, J. A.; González, Y.; Iglesias, A.; Zian, D.; Lishchynskyi, A.; Muñiz, K. Chem. Asian J. 2012, 7, 1103. (c) Röben, C.; Souto, J. A.; EscuderoAdán, E. C.; Muñiz, K. Org. Lett. 2013, 15, 1008.

(11) (a) Farid, U.; Malmedy, F.; Claveau, R.; Albers, L.; Wirth, T. Angew. Chem. Int. Ed. 2013, 52, 7018. (b) Mizar, P.; Wirth, T. Angew. Chem. Int. Ed. 2014, 53, 5993. (c) Uyanik, M.; Yasui, T.; Ishihara, K. Angew. Chem. Int. Ed. 2010, 49, 2175. (d) Uyanik, M.; Yasui, T.; Ishihara, K. Tetrahedron 2010, 66, 5841. (e) Zhang, D.Y.; Xu, L.; Wu, H.; Gong, L.-Z. Chem. Eur. J. 2015, 21, 10314.

(12) (a) Farid, U.; Wirth, T. Angew. Chem. Int. Ed. 2012, 51, 3462. (b) Kong, W.; Feige, P.; de Haro, T.; Nevado, C. Angew. Chem. Int. Ed. 2013, 52, 2469.

(13) For a conceptually different approach on enantioselective dichlorination with a combination of $\mathrm{ArICl}_{2}$ and (DHQD) $)_{2} \mathrm{PHAL}$, see: Nicolaou, K. C.; Simmons, N. L.; Ying, Y.; Heretsch, P. M.; Chen, J. S. J. Am. Chem. Soc. 2011, 133, 8134.

(14) (a) Fujita, M.; Mori, K.; Shimogaki, M.; Sugimura, T. Org. Lett. 2012, 14, 1294. (b) Fujita, M.; Mori, K.; Shimogaki, M.; Sugimura, T. RSC Adv. 2013, 3, 17717. (c) Shimogaki, M.; Fujita, M.; Sugimura, T. Eur. J. Org. Chem. 2013, 7128.

(15) For reviews on iodine(III) catalysis, see: (a) Richardson, R. D.; Wirth, T. Angew. Chem. Int. Ed. 2006, 45, 4402. (b) Ochiai, M.; Miyamoto, K. Eur. J. Org. Chem. 2008, 4229. (c) Ochiai, M. Chem. Rec. 2007, 7, 12. (d) Dohi, T.; Kita, Y. Chem. Commun. 2009, 2073. (e) Uyanik, M.; Ishihara, K. Chem. Commun. 2009, 2086.
(16) See refs. 5a, 6 and (a) Celik, M.; Alp, C.; Coskun, B.; Gültekin, M. S.; Balci, M. Tetrahedron Lett. 2006, 47, 3659. (b) Tellitu, I.; Domínguez, E. Tetrahedron 2008, 64, 2465. (c) De Mico, A.; Margarita, R.; Parlanti, L.; Piancatelli, G.; Vescovi, A. Tetrahedron 1997, 53, 16877. (d) Koser, G. F.; Rebrovic, L.; Wettach, R. H. J. Org. Chem. 1981, 46, 4324. (e) Moriarty, R. M.; Vaid, R. K.; Koser, G. F. Synlett 1990, 365. (f) Zefirov, N. S.; Zhdankin, V. V.; Dan'kov, Y. V.; Sorokin, V. D.; Semerikov, V. N.; Koz'min, A. S.; Caple, R.; Berglund, B. A. Tetrahedron Lett. 1986, 27, 3971.

(17) Richardson, R. D.; Desaize, M.; Wirth, T. Chem. Eur. J. 2007, 13, 6745.

(18) Haubenreisser, S.; Wöste, T. H.; Martínez, C.; Ishihara, K.; Muñiz, K. Angew. Chem. Int. Ed. 2015, 54, in press; DOI: 10.1002/anie.201507180.

(19) Kang, Y.-B.; Gade, L. H. J. Am. Chem. Soc. 2011, 133, 3658.

(20) For a related $\mathrm{BF}_{3}$ activation, see: Zhong, W.; Yang, J.; Meng, $\mathrm{X}$.; $\mathrm{Li}$, Z. J. Org. Chem. 2011, 76, 9997.

(21) Zhong, W.; Liu, S.; Yang, J.; Meng, X.; Li, Z. Org. Lett. 2012, 14, 3336.

(22) Kang, Y.-B.; Gade, L. H.J. Org. Chem. 2012, 77, 1610.

(23) (a) Ye, C.; Twarnley, B.; Shreeve, J. M. Org. Lett. 2005, 7, 3961. (b) Dohi, T.; Mochizuki, E.; Yamashita, D.; Miyazaki, K.; Kita, Y. Heterocycles 2014, 88, 245. (c) Dohi, T.; Maruyama, A.; Takenaga, N.; Senami, K.; Minamitsuji, Y.; Fujioka, H.; Caemmerer, S. B.; Kita, Y. Angew. Chem. Int. Ed. 2008, 47, 3787. (d) Uyanik, M.; Yasui, T.; Ishihara, K. Tetrahedron 2010, 66, 5841.

(24) Crystal structure analyses data of compounds $\mathbf{5 c}$, $\mathbf{d}$ were deposited with the Cambridge Crystallographic Data Centre (CCDC). They can be obtained from the $\operatorname{CDDC}$ (e-mail: deposit@ccdc.cam.ac.uk) citing the following numbers: CCDC $996364(\mathbf{5 c})$ and CCDC 996363 (5d).

(25) Prévost, C. Compt. Rend. 1933, 196, 1129.

(26) Woodward, R. B.; Brutcher, F. V. Jr. J. Am. Chem. Soc. 1958, 80, 209.

(27) (a) Ochiai, M. In Chemistry of Hypervalent Compounds; Akiba, K., Ed.; Wiley-VCH: New York, 1999, 359. (b) Okuyama, T.; Takino, T.; Sueda, T.; Ochiai, M. J. Am. Chem. Soc. 1995, 117, 3360.

(28) Koser, G. F.; Rebrovic, L.; Wettach, R. H. J. Org. Chem. 1981, 46, 4324.

(29) At present, the scope of the new dioxygenation catalysis remains limited to aryl substituted alkene classes such as $\mathbf{2}$ and 7. This is in agreement with the observation from the corresponding stoichiometric transformations outlined in refs. 9 and 18. Further catalyst development is required to address this point.

(30) Chatterjee, P. N.; Roy, S. Tetrahedron 2012, 68, 3776.

(31) (a) Wiedemann, S. H.; Ellman, J. A.; Bergman, R. G. J. Org. Chem. 2006, 71, 1969. (b) Kim, E.; Koh, M.; Lim, B. J.; Park, S. B. J. Am. Chem. Soc. 2011, 133, 6642. (c) Fabio, K.; Guillon, C.; Lacey, C. J.; Lu, S.-f.; Heindel, N. D.; Ferris, C. F.; Placzek, M.; Jones, G.; Brownstein, M. J.; Simon, N. G. Bioorg. Med. Chem. 2012, 20, 1337. (d) Bambler, B. R.; Altman, R. A. Org. Lett. 2013, 15, 5578. (e) Lölsberg, W.; Ye, S.; Schmalz, H.-G. Adv. Synth. Catal. 2010, 352, 2023.

(32) Hu, D. X.; Shibuya, G. M.; Burns, N. Z.J. Am. Chem. Soc. 2013, 135, 12960.

(33) Fujita, M.; Wakita, M.; Sugimura, T. Chem. Commun. 2011, 47, 3983.

(34) Studte, C.; Breit, B. Angew. Chem. Int. Ed. 2008, 47, 5451. 